\title{
ETHANOL EXTRACT OF MANGOSTEEN PEEL REDUCES HISTOLOGICAL COUNT OF ALVEOLAR MACROPHAGE AND PULMONARY ALVEOLAR SPACE SIZE IN MALE WHITE RATS (Rattus norvegicus) EXPOSED TO CIGARETTE SMOKE
}

\author{
Anna Lewi Santoso \\ Master Program on Basic Medical Science \\ Faculty of Medicine, Universitas Airlangga
}

\begin{abstract}
ABSTRAK
Penelitian ini bertujuan menganalisa gambaran histologi jumlah sel makrofag alveolar dan lebar ruang alveolar paru tikus putih jantan (Rattus norvegicus) yang diberi ekstrak etanol kulit buah manggis lalu dipapar asap rokok. Rokok dapat menurunkan antioksidan dan meningkatkan radikal bebas, sehingga dianjurkan meningkatkan antioksidan yang banyak terdapat pada kulit buah manggis. Penelitian ini eksperimental laboratories dengan menggunakan the randomized post test-only control group design. Tiga puluh tikus putih jantan dikelompokkan secara acak menjadi 5 kelompok (K1, K2, P1, P2, P3). K1 (kontrol-), diberi Na-CMC 0,5\%, K2 (kontrol+) diberi Na-CMC 0,5\% dan asap rokok, P1, P2, P3 diberi ekstrak etanol kulit buah manggis (50, 100, dan $200 \mathrm{mg} / \mathrm{kgBB}$ ) dan asap rokok. Data diuji normalitas dan homogenitas, dianalisa dengan uji Anova one-way, LSD. Data yang tidak normal diuji Robust tests - (Brown-Forsythe) dan Tamhane's. Uji korelasi dengan Pearson dan Spearman. Hasil Robust tests, jumlah sel makrofag alveolar, nilai $p=0,000(p<\alpha)$. Hasil uji tamhane's kelompok K1 signifikan dengan K2 dan P3. Kelompok K2 signifikan dengan P1, P2,P3. P1 signifikan dengan P3. Uji korelasi Spearman terdapat korelasi negatif antara dosis dengan jumlah sel makrofag dan dosis dengan lebar ruang alveolar. Hasil uji Anova one-way variabel rerata lebar ruang alveolar, nilai $p=0,000$ $(p<\alpha)$. Hasil uji LSD terdapat perbedaan signifikan antara kelompok, kecuali kelompok P1 dengan P2,P3 dan P2 dengan P3. Simpulan penelitian adalah ekstrak etanol kulit buah manggis dapat mengurangi jumlah sel makrofag alveolar dan mengurangi lebar ruang alveolar paru tikus putih jantan yang dipapar asap rokok. (FMI 2015;51:234-244)
\end{abstract}

Kata kunci: buah manggis, rokok sel makrofag alveolar, ruang alveolar

\begin{abstract}
This study aims to analyze histological alveolar macrophage cell number and width of pulmonary alveolar space white male rats given ethanol extract of mangosteen peel and then exposed to cigarette smoke. Smoking can reduce antioxidant and increases free radicals, so it is recommended increasing the antioxidants found in many mangosteen rind. This research was an experimental laboratory using the randomized post test-only control group design. White rats male were chosen randomly into 5 groups (K1, K2, $P 1, P 2, P 3) . K 1$ (control-), only the Na-CMC 0.5\%, K2 (control+) given Na-CMC $0.5 \%$ solution and smoke, P1, P2, P3 given the ethanol extract of mangosteen rind $(50,100$, and $200 \mathrm{mg} / \mathrm{kg} w \mathrm{w})$ and smoke. The data were tested normality and homogenity. Then they were analyzed with one-way Anova, LSD. Data that are not normally tested with Robust tests - (Brown-Forsythe) and Tamhane's. Correlation test with Pearson and Spearman. Robust test results, the number of alveolar macrophages, value $p=0.000$ $(p<\alpha)$. Tamhane's test results K1 significant with P1, P2, P3. P1 significant with P3. Spearman correlation test negative correlation between dose and the number of alveolar macrophage also negative correlation between dose and pulmonary alveolar space. Anova test results, the average variable width of the alveolar spaces, value $p=0.000(p<\alpha)$. LSD test results are significant differences between the groups, except the group P1 to P2, P3 and P2 to P3. Conclusions of this study is the ethanol extract of mangosteen peel can reduce the number of alveolar macrophage cells and reduce the width of pulmonary alveolar space white male rats were exposed to cigarette smoke. (FMI 2015;51:234-244)
\end{abstract}

Keywords: mangosteen, cigarette smoke, alveolar macrophage cell, pulmonary, alveolar space

Correspondence: Anna Lewi Santoso, Jalan Darmo Permai Utara XI no 59, Surabaya, Indonesia. Phone: 08123546809. Email: lew_an@yahoo.com

\section{INTRODUCTION}

Mangosteen peel beneficial for health because it contain anthocyanin, tannin, compound phenol/polyphenol, epikathekin and xanthone, which act as antioxidants, antidiabetic, anticancer, anti inflammatory, hepatoprotective, antibacteri. Mangosteen peel contains an average of total anthocyanin content is 59.3 miligram/ 100 gram. Mangosteen peel extract has antioxidant activity to the value of EC50 is $8.5539 \mu \mathrm{g} / \mathrm{mL}$. Means it has a very strong antioxidant power, because the value of EC50 is less than $50 \mu \mathrm{g} / \mathrm{mL}$ (Wiwin et al 2010). Xanthone as a strong anti-inflammatory by inhibiting 1 . Allergic process by reducing the release of histamine 
prostanoids synthesis through inhibition of activity COX (cyclooxygenase). 2. Increase ICAM-I by induced TNF- $\alpha$ in endothelial cells. 3. Increase adhesion of monocytes to endothelial cells and increase in TNF- $\alpha$ and monocyte chemoattractant protein (MCP-1) posed by OX-LDL on endothelial cells. 4. Platelet aggregation and release ATP arising from several agonists including ADP, arachidonic acid, PAF, colagen, ion A23187, reduce the formation of platelets via inhibition $\mathrm{COX}$. 5 . $\mathrm{PAF}$ receptor and inhibit binding PAF to platelets in vitro and increase the level cAMP (intraseluler cyclic adenosine 3-5 monophosphate) but not increase cyclic guanosit 3.5 monophosphate (cGMP) (Jiang et a1 2004).

One of the highest xanthone derivative is $\alpha$-mangostin. Pharmacokinetics of $\alpha$-mangostin is $36 \mathrm{mg} / \mathrm{Kg}$ in mice that received the $100 \mathrm{mg} / \mathrm{Kg}$ have $\mathrm{Cmax} 1382 \mathrm{nmol} / \mathrm{L}$. Tmax 0,5 hour, half-life 5 hours. Dose in humans approaching $500 \mathrm{mg}$ weight of $60 \mathrm{~kg}$. The study shows $100 \mathrm{mg} / \mathrm{Kg}$ extract $\mathrm{Cmax} \pm 497 \mathrm{nmol} / \mathrm{L}$ in $\alpha$-mangostin $36 \%$. The half-life increased from 5 - 8 (Petiwala et al 2014). Invitro mangostin is a scavenger potential for ONOO, O2 and O2-. So $\alpha$-mangostin is a direct function of scavenge some ROS and neuroprotective against 3 nitropropionic acid the nerve cerebellum (Lei et al 2014). Isogentisin Xanthone can inhibit cell death by activating the function of cell repair or prevent damage to DNA caused by smoking. So the best strategy for the therapy of disease caused by smoking is prevention (Schmieder et al 2007).

More than 1 billion people worldwide are smokers, most will or already suffering from the disease because of smoking. Smoking causes endothelial dysfunction in vivo, thereby decreasing the flow of blood vessel dilation due process, thus undermining the ability of blood vessel to NO, consequently there will be NO physiological changes become peroxynitrit (ONOO). The second key principle is the mikrolesi in endothelial. Cell death induced hydrogen peroxide so that the cell necrosis (Schmieder et al 2007).

Bronchogenic carcinoma or lung cancer generally occurs due to smoking, which is spread through the lymphatic system. Cancer cells can enter the systemic circulation through walls sinusoid or venules in the lungs, the cancer cells will spread through the pulmonary vein, the left ventricle, aorta and then to all parts of the body, especially to the skull and brain. (Moore et al 2002). Alveolar macrophage in the form of a large cell with a diameter 15-50 $\mu \mathrm{m}$, located in interalveolar septa. Alveolar macrophages have a single cell nucleus that is located in the middle of the cell. Cytoplasm contains lysosomes organelles primary and secondary, as well as carbon particles (Ovalle \& Nahirney 2008).

Alveolar macrophage/dust cell had phagocyte foreign body in the lumen of the alveoli and septum interalveolar. Monocytes that reach the lung interstitium access to the network will become alveolar macrophage/dust cell, which migrate between pneumocyte type I and into the lumen of the alveoli. The cells will phagocyte particles, such as dust and bacteria, to sterilize the environment in the lung. Dust cell also help the pneumocyte type II to take the surfactant. Approximately 100 million macrophage migrate to the bronchial every day and transported through the bronchial cilia movement towards the pharynx to be removed by means of swallowed or coughed. Some alveolar macrophages will go back into the lung interstitium and migrate into the lymph vessels to get out of the lungs (Junqueira et al 2005).

Pulmonary disorders associated with smoking is COPD, ie emphysema, chronic bronchitis and lung cancer. The Pathogenesis of COPD is characterized by chronic inflammation throughout the airways, parenchyma, and pulmonary vasculature. Alveolar macrophage, limphocyte T CD8+, and neutrophil increased in various parts of the lung. Active inflammatory cells secrete a variety of mediators, including leucotriens 84, IL-8, TNF, which are capable of damaging lung structures or maintain neutrophil inflammation (Kumar et a1 2005). In diameter emphysema abnormal enlargement of air spaces of the lung alveolar wall accompanied by damage to walls without significant fibrosis (Wilkins \& Gold 2007).

The most likely hypotheses to explain the mechanism of damage to the walls of the alveoli are proteasesantiproteases, which is reinforced by an imbalance of oxidan-antioxidan. Proteases-antiproteases theory states that the alveolar wall damage caused by an imbalance between diastase and antiproteases in the lung. Antielastase activity especially in serum and tissue interstitium is $\alpha 1-\mathrm{AT}$, and the elastase activity of primary cells derived from neutrophils, elastase others formed by alveolar macrophage, mast cells, pancreas and bacteri. In emphysema due to smoking, which is the role of neutrophil proteases, alveolar macrophage, also the accumulation of T CD8+ cells by causing apoptosis of alveolar epithelial cells (Kumar et al 2005).

Smoking causes an increase or decrease in the activity of elastase antielastase. Neutrophil and alveolar macrophage accumulation occur in the alveoli. Inflammatory mechanism is not very clear, there is a direct chemoattractant effects of nicotine and the effects ROS contained in cigarette smoke. Then activated neutrophil 
accumulate and secrete granules rich with cell protease is elastase, proteinase 3 , and katepsin $\mathrm{G}$ resulting in tissue damage. Smoking also increases elastase activity in macrophage, macrophage elastase not resistor by $\alpha 1$ antitripsin and can even be proteolytic digest this antiproteases. Smoking also plays a role in the oxidantantioxidant imbalance in the pathogenesis of emphysema. Pulmonary normally contain a number of antioxidants that superoxide dismutase, glutathione minimize oxidative damage. Cigarette smoke contains many ROS or free radicals, which interfere with the mechanisms of antioxidant resulting in tissue damage. Neutrophil active also increased the number of ROS in the alveoli. Secondary consequences of oxidative injury is the inactivation of antiproteases causing functional deficiency $\alpha 1-\mathrm{AT}$ (Kumar et al 2005).

There is a brief explanation of smoke particle collisions, especially in the respiratory bronchioles branch, which led to an influx of neutrophils and macrophage, and both are then issued various protease. Increased activity of protease localized sentriasinus section, along with oxidation due to the smoke, which causes the formation of emphysema in smokers sentriasinus. Become more severe tissue damage due to inactivation of antiproteases protective by ROS from cigarette smoke (Wilkins \& Gold 2007).

Microscopic emphysema, alveoli looks great, separated by a thin septum obtained with only focal fibrosis sentriasinus. Alveolar attachment to the outer wall of the airway disappear. Khon pores so large that simply septum protruding into the alveolar cavity with a maceshape tip. The progress of the disease, the air space becomes larger and can even be shaped bleb or bullae. Respiratory bronchioles and the pulmonary veins are often deformed and depressed by the distortion emphysematous air spaces, and as already mentioned, often there bronchiolitis or chronic bronchitis (Kumar et al 2005).

Histological findings of the most striking is the accumulation of a large number of macrophage with plenty of cytoplasm containing brown pigment (smoker's macrophage) in the air cavity. Look fine granular iron in the cytoplasm of macrophage. Partly macrophage containing surfactant lamellar bodies in phagocytic vacuoles, which are derived from type 2 pneumocytes necrotic. Alveolar septum thickened by infiltration of lymphocytes and eosinophils sometimes. Septum lined by plump cuboidal pneumocytes. Interstitium fibrosis if any, are minor. Often there emphysema (Kumar et al 2005).

Lung cancer is currently the primary cancer is most often diagnosed in the world and is the most common cause of cancer deaths worldwide. This is mainly due to the carcinogenic effect of cigarette smoke. In the next few decades will change smoking habits greatly influence the incidence and mortality of lung cancer as well as the prevalence of various histological types of lung cancer. Relationship with cigarettes found in squamous cell carcinoma and small cell carcinoma (Kumar et a1 2005).

Treatment with antioxidant, especially polyphenols are very effective against cancer cells. When the normal balance between anti and pro oxidants missing, ROS high doses would interfere with the function of antioxidants, it is necessary to supplement antioxidants to fight these ROS. The concentration of synthetic antioxidants is important to improve the cellular response, but high concentrations can affect otherwise called pro-oxidant (Sosa et al 2013). Low antioxidant and free radical increased in smokers has proven that cigarette contain a high oxidant. So it is advisable for smoker to consume antioxidants found in food. In smokers, lipid peroxidation in significant higher levels in erythrocytes by measuring MDA. Smoking associated with lower concentrations SOD and ascorbic acid, which can increase free radicals, thus decreasing the antioxidant defense system. Smoking also decreases the circulation of the body's antioxidant so it takes more antioxidants to prevent free radical (Jain et al 2009).

Proinflammatory expression in the lung by smoking will produce ROS involved in the inflammatory process of lung. ROS formation process in mammals through Nicotinamid adenine dinucleotida phosphat (NADPH) oxidase, which play a role in genetic targets guard against the effects of smoking are lung phosphatase p47 and phosphatase gp 91 which will happen genetic ablation (Yao et al 2008).

Inflammatory response will release proinflammatory mediators resulting in widening of lower airway and alveolar damage. Pathology associated with the activation of TLR4 nuclear factor- $\beta$. Smoking is estimated to have as many free radicals in 1015-1017 and more than 4700 chemical components including aldehyde reactive substance, quinone, and semiquinone, per trunk (Yao et al 2008).

Smoking is the main factor of the development of COPD, the lung increase in inflammatory cells such as alveolar macrophage, neutrophil, dendritic cells, and CD8-T, lymphocyte. Inflammatory cells will release ROS, inflammatory mediators and proteinases which progressively damage the lungs, causing emphysema. Oksidation Nicotinamid adenine dinucleotid phosphat (NADPH) containing phagocytic cells and nonphagocytic cells. Translocation occurs when activated 
cell cytoplasm to the cell membrane component which binds to flavocytochrom b558 and form an active oxidizing NADPH. NADPH formed will catalyze the oxidation of electron transfer from NADPH to molecular oxygen, so oxygen producing superoxide anion (O2-), hydroxyl radicals and hydrogen peroxide (Yao et a1 2008).

In vivo lung damage histologically with the presence of inflammatory response and oxidative stress due to exposure to cigarette smoke. In the first hour of stress, there is an inflammatory response in the form of increased epithelial permeability, neutrophil, alveolar macrophage. In vitro, after 1 hour alveolar macrophage cells exposed to cigarette smoke will release inflammatory mediators, Il-1 $\beta$ and monocyte chemoattractant protein-1(MCP-1) which will cause the nuclear translocation of $(\mathrm{NF}) \kappa \mathrm{B}$. Pro-inflammatory stimuli in the form of hyperosmolaritas and hypercapnia will cause transduction PP2A, NF- $\kappa \mathrm{B}$ who will control the translocation from the cytoplasm to the nucleus.

In theory, smoking is the main factor causing emphysema, in research with mice exposed to smoke a decline in serum elastase inhibitor capacity (EIC) also on human lung fluid. EIC decline is not the result of a decrease in the levels of $\alpha$ lPI but of the formation of the protein inactive the rest of the oxidation of methionine. Although only one methionine residue at the active site but very essential $\alpha$ IPI binds to the protein elastase (Church \& Pryor 1985). Cigarette inactivate Glukosa 6phosphate dehydrogenase and an enzymes containing thiol, resulting in changes in lung cells and become malignant. Thiol especially damage in the gas phase is NO (Church \& Pryor 1985). Smoking is a major risk factor of respiratory tract inflammation. Inflammation is key Cyclooxygenase and COX-2 dependent factor of apoptosis resistance. Smoking causes chronic inflammation with the following steps, the transformation of the epithelium, the angiogenesis and suppress apoptosis.

Smoking is potentially damaging to the lungs, with their relationship with humic acid as reversible change of ferritin iron-catalysed. Humic acid can release divalent iron which is the result of smoking reduction and binds to alveolar macrophage causing bond with ferritin. Release of iron can catalyze and produce ROS lung damage by oxidation. Deposits of iron in the form of pulmonary emphysema materials blackish brown. Iron in alveolar macrophage is very high in smokers. Cytotoxicity intracellular humic acid because smoking is detected from alveolar macrophage. Alveolar macrophage in vivo study contains a large amount of humic acid. Humic acid from dead cells can be taken up by alveolar macrophage, as evidenced by the increase in alveolar macrophage. Which plays an important role in the pathogenesis of emphysema is IL- 8 chemokine. Humic acid can induce IL-8 of monocytes, oxidative stress and ROS, also induces the release of cytokines and lymphocytes in perivaskuler dan peribronchial (van Eijl et al 2011). This study aims to analyze histological alveolar macrophage cell number and width of pulmonary alveolar space white male rats given ethanol extract of mangosteen peel and then exposed to cigarette smoke.

\section{MATERIALS AND METHODS}

The experimental animals in this study were male rats (Rattus norvegius), age 2-3 month, weight about 160170 grams, as many as 30 individuals adapted/acclimatization in advance for 1 week. Mice were randomly assigned into 5 groups, each group consisting of 6 animals. The test material used ethanol extract of mangosteen peel and cigarette smoke (non filter cigarettes manufactured).

Mice weighed after acclimatized for 1 week. The K1 group given a solution $\mathrm{Na}-\mathrm{CMC} 0.5 \%$ on day 8 to day 21. The K2 group was given a solution Na-CMC $0.5 \%$ and smoke (3 sticks every morning) on day 8 to day 21 . The P1 group given ethanol extract of mangosteen peel $50 \mathrm{mg} / \mathrm{kg}$ wt and smoke on day 8 to day 21 . The P2 group given ethanol extract of mangosteen peel $100 \mathrm{mg} / \mathrm{kg}$ wt and smoke on day 8 to day 21 . The P3 group given ethanol extract of mangosteen peel $200 \mathrm{mg} /$ $\mathrm{kg}$ wt and smoke on day 8 to day 21. On day 22, performed termination, organ harvesting, making preparations histology with HE staining (hematoxylin eosin) and observation under light microscopic. Lung samples obtained from the edge of the lung (alveolar sacs) with longitudinal section. Making preparations lung histology using paraffin and staining techniques HE (Haematoxylin-Eosin).

Data obtained by observation under a light microscope Olympus DP21. Each lung preparations male rats (Rattus norvegicus) seen with 400x and seen 4 visual field, each field of view was calculated alveolar macrophage cell count and measured extensive alveolar space as much as 5 space, so that each preparation is obtained four times the amount of alveolar macrophages and 20 area of alveolar space, which the average will be taken.

The result are calculated by descriptive statistics for the mean and standard deviation. The data were tested with one sample Kalmogorov-Smirnov for normality and Levene test for homogenity. Then the normal distribution and homogeny data was analyzed with one-way Anova test, and LSD (Least Significant Different). Abnormal distributed data were analyzed with Robust 
test (Brown-Forsythe) and Tamhane's test. Pearson correlation test with test when normal data distribution and Spearman test if data distribution is not normal.

\section{RESULTS}

\section{Alveolar macrophage cell}

Data on the number of alveolar macrophage cell of each group can be seen in the table 1 .
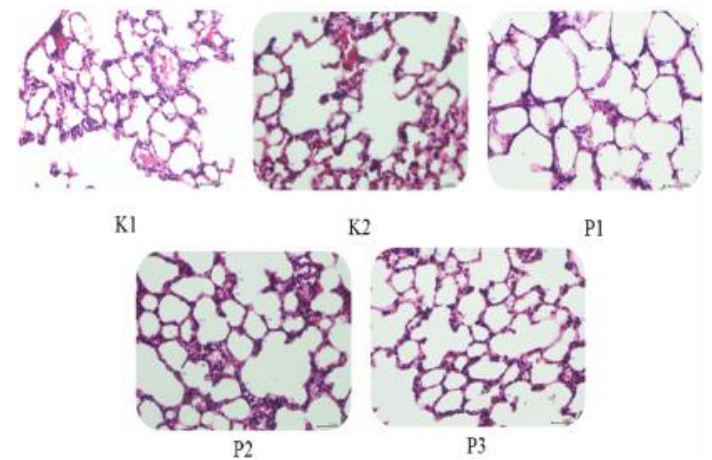

Figure 1. Alveolar macrophage cell lung male rats with staining HE, seen through the light microscope Olympus DP21 with 400x magnification

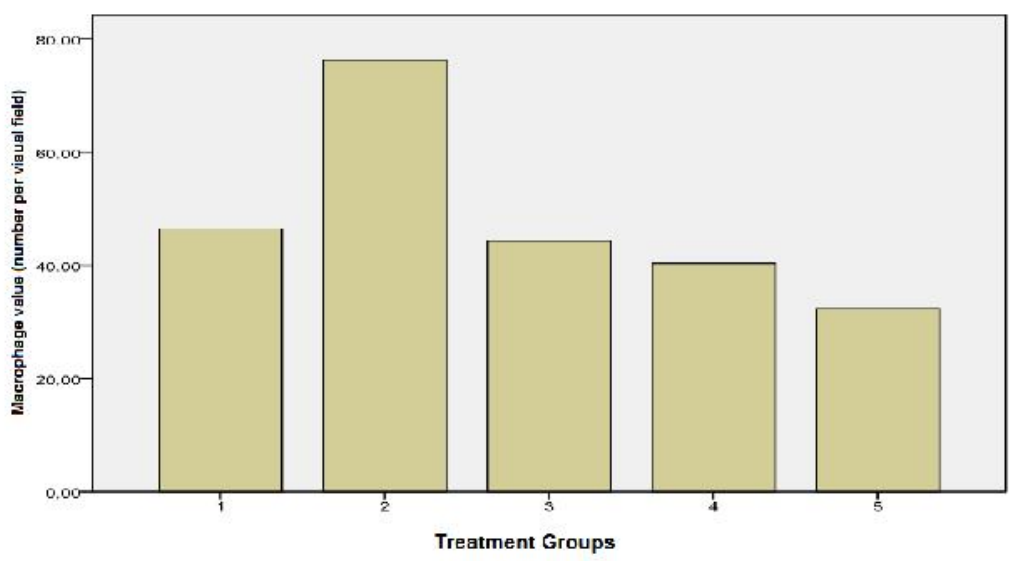

Figure 2. The average number alveolar macrophage cell

Description:

$\mathrm{K} 1$ : the group of mice given a solution Na-CMC $0.5 \%$.

$\mathrm{K} 2$ : the group of mice given a solution $\mathrm{Na}-\mathrm{CMC} 0.5 \%$. and smoke.

$\mathrm{P} 1(3)$ : the group of mice given ethanol extract of mangosteen peel $50 \mathrm{mg} / \mathrm{kg}$ wt and smoke.

$\mathrm{P} 2(4)$ : the group of mice given ethanol extract of mangosteen peel $100 \mathrm{mg} / \mathrm{kg}$ wt and smoke.

$\mathrm{P} 3(5)$ : the group of mice given ethanol extract of mangosteen peel $200 \mathrm{mg} / \mathrm{kg}$ wt and smoke.

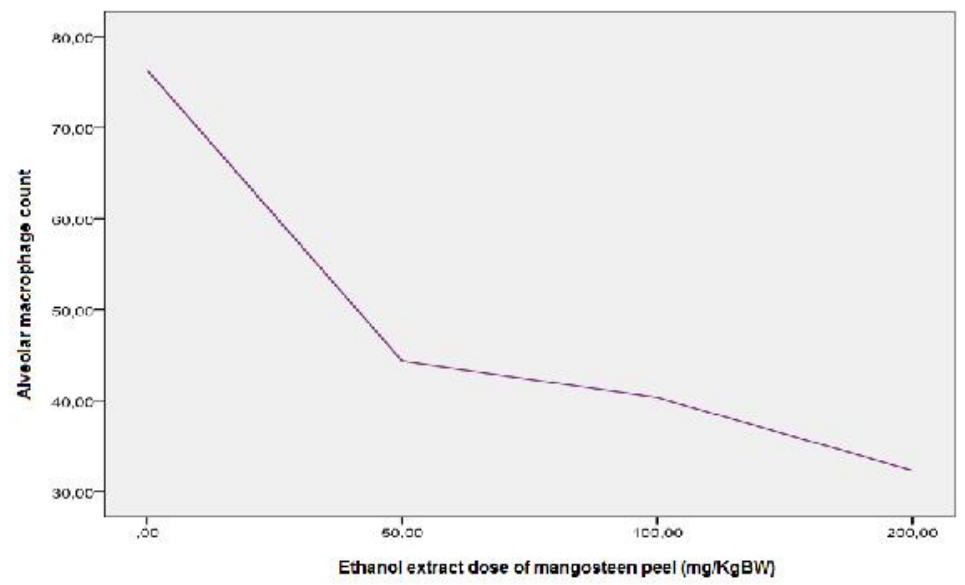

Figure 3. Linear graph between doses of ethanol extract of mangosteen peel and the number of alveolar macrophage cells. 
After entering data into a statistical software, then the data will be analyzed descriptively and analytic. Data number mean alveolar macrophage cells first tested for normality with Shapiro-Wilk test $(\alpha=0.05)$ as shown in Table 1. Based on the result in Table 1, the homogeneity test was carried out (Table 2).

Table 1. Normality test data on the number of alveolar macrophage cells

\begin{tabular}{lll}
\hline Group & Mean \pm SD & p \\
\hline K1 & $46.50 \pm 6.89$ & 0.398 \\
K2 & $76.33 \pm 13.82$ & 0.372 \\
P1 & $44.33 \pm 5.75$ & 0.915 \\
P2 & $40.33 \pm 6.89$ & 0.635 \\
P3 & $32.33 \pm 3.50$ & 0.593 \\
\hline
\end{tabular}

Table 2. Homogeneity test

\begin{tabular}{ll}
\hline \multicolumn{1}{c}{ Variable } & Sig. \\
\hline $\begin{array}{l}\text { Number of } \\
\text { alveolar } \\
\text { macrophage } \\
\text { cells }\end{array}$ & 0.004 \\
\hline
\end{tabular}

Based on table 2 obtained value $\mathrm{p}<\alpha$ which means that data si not homogeneous, then tested with Anova (Robust tests - Brown-Forsythe) obtained value $\mathrm{p}=0.000$ $(p<\alpha)$, means that there are significant differences between the data variance number of alveolar macrophage cells $(\alpha=0.05)$. Each group then performed Post Hoc test with Tamhane's T2 test to see the differences in each group. Then obtained the data in the table 3

Table 3. Tamhane's T2 test

\begin{tabular}{lll}
\hline & & $\mathrm{p}$ \\
\hline $\mathrm{K} 1$ & $\mathrm{~K} 2$ & $0.019^{\mathrm{a}}$ \\
& $\mathrm{P} 1$ & $1.000^{\mathrm{b}}$ \\
& $\mathrm{P} 2$ & $0.808^{\mathrm{b}}$ \\
& $\mathrm{P} 3$ & $0.024^{\mathrm{a}}$ \\
\hline $\mathrm{K} 2$ & $\mathrm{P} 1$ & $0.014^{\mathrm{a}}$ \\
& $\mathrm{P} 2$ & $0.006^{\mathrm{a}}$ \\
& $\mathrm{P} 3$ & $0.004^{\mathrm{a}}$ \\
\hline P1 & $\mathrm{P} 2$ & $0.972^{\mathrm{b}}$ \\
& $\mathrm{P} 3$ & $0.022^{\mathrm{a}}$ \\
\hline P2 & P3 & $0.315^{\mathrm{b}}$ \\
\hline
\end{tabular}

Based on table 3 shows that significant between the K1 group and K2, P3 groups. The K2 group were significant with $\mathrm{P} 1, \mathrm{P} 2, \mathrm{P} 3$ groups and $\mathrm{P} 1$ with $\mathrm{P} 3$ with value. Otherwise it obtained non-significant between $\mathrm{P} 1$ group and P2 group with value $\mathrm{p}=0.022$., $\mathrm{P} 2$ group and
$\mathrm{P} 3$ group with value $\mathrm{p}=0.315$. Prior to the correlation test, normality test on group K2, P1, P2, P3 (24 rats).

Table 4. Shapiro-Wilk test normality.

\begin{tabular}{lc}
\hline \multicolumn{1}{c}{ Groups } & $\mathrm{p}$ \\
\hline Dose & 0.001 \\
Macrophage & 0.002 \\
Alveolar & 0.402 \\
\hline
\end{tabular}

Correlation between ethanol extract of mangosteen peel with doses of $0,50 \mathrm{mg} / \mathrm{Kg}, 100 \mathrm{mg} / \mathrm{Kg}$ and $200 \mathrm{mg} / \mathrm{Kg}$ and the amount of alveolar macrophage have a distribution is not normal, then using the Spearman correlation test $(\alpha=0.05)$ found a significant negative correlation $(\mathrm{p}=0.000 . \mathrm{C}=-883)$, meanings the greater the dose will be smaller number of alveolar macrophage cells.

\section{Pulmonary alveolar space width}

Data mean pulmonary alveolar space width in each group are shown in table 5. After entering data into a statistical software, then the data will be analyzed descriptively and analytic. Data mean pulmonary alveolar space width first tested for normality with Shapiro-Wilk test $(\alpha=0.05)$ as shown in Table 5 .

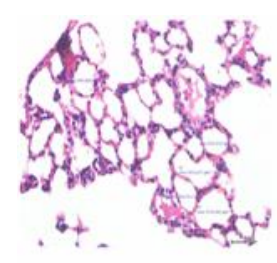

$\mathrm{K} 1$

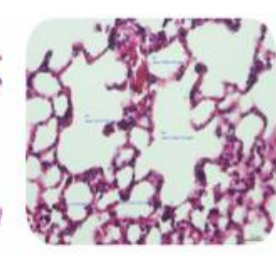

K2

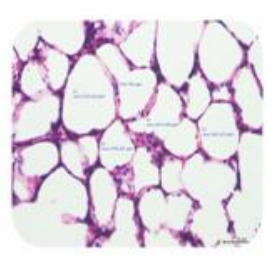

P1

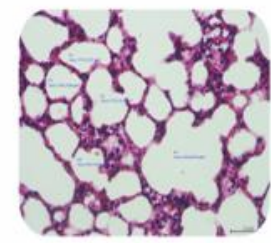

P2

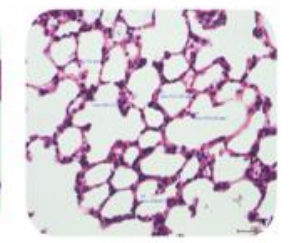

P3
Figure 4. Pulmonary alveolar space width lung male rats with staining $\mathrm{HE}$, seen through the light microscope Olympus DP21 with 400x magnification. 


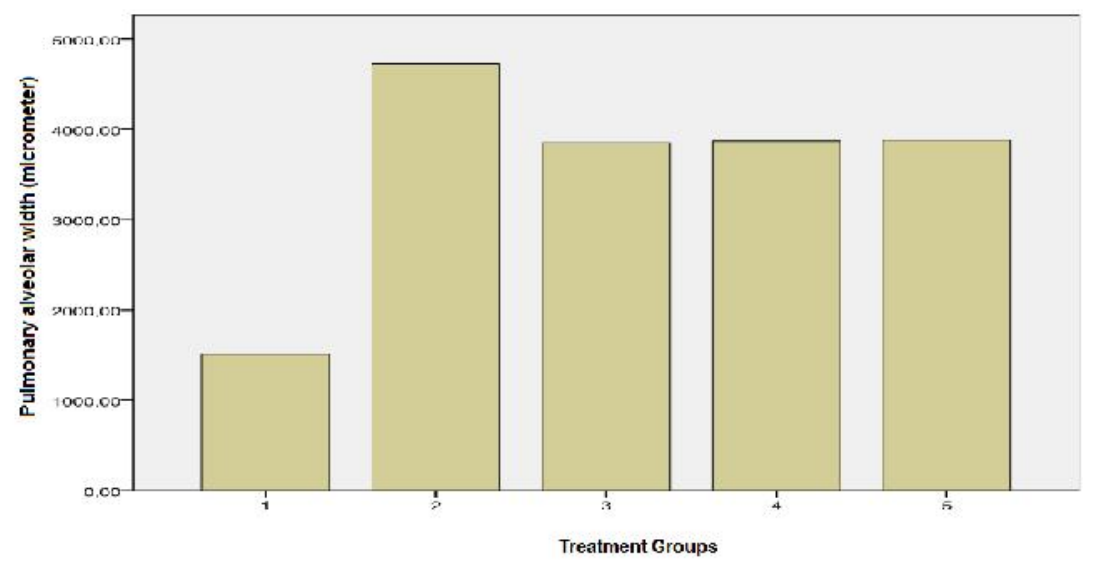

Figure 5. Average pulmonary alveolar space width.

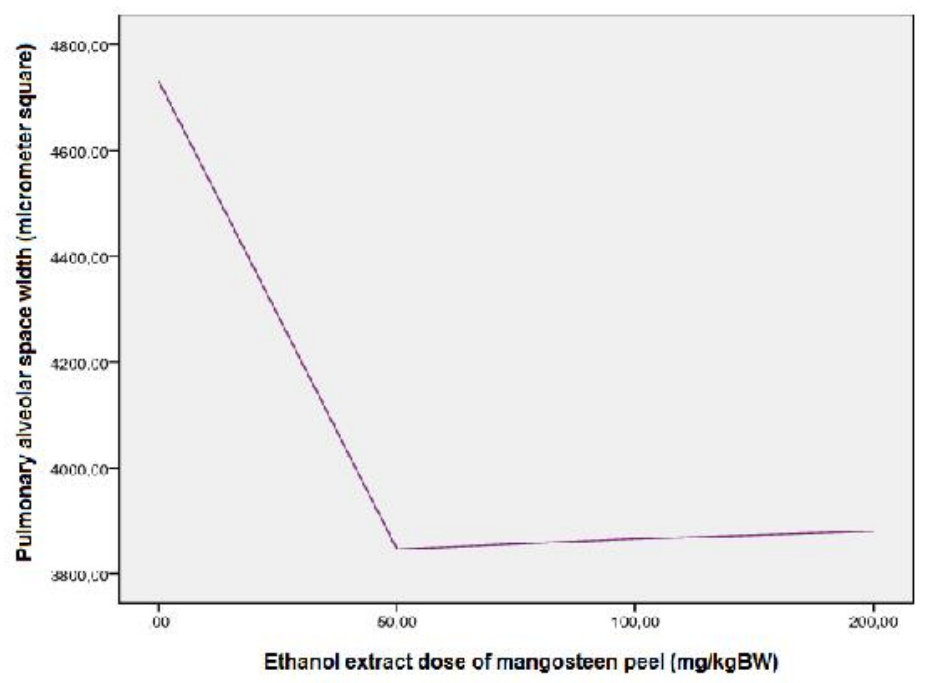

Figure 6. Linear graph between doses of ethanol extract of mangosteen peel and the pulmonary alveolar space width.

Table 5. Test data normalitas mean pulmonary alveolar space width.

\begin{tabular}{clr}
\hline Group & Mean \pm SD & p \\
\hline K1 & $1512.49 \pm 249.13$ & 0.396 \\
K2 & $4731.35 \pm 674.17$ & 0.973 \\
P1 & $3846.64 \pm 634.55$ & 0.033 \\
P2 & $3865.81 \pm 638.14$ & 0.587 \\
P3 & $3880.32 \pm 1055.82$ & 0.368 \\
\hline
\end{tabular}

Based on the results in table 5, then the homogeneity test as seen in Table 6 .

After the data were analyzed with Anova one-way test value $\mathrm{p}=0.000(\mathrm{p}<\alpha)$ so that the data there are significant differences. Each group then performed LSD test (Least Significant Differences), obtained the data as in Table 7.
Table 6. Homogeneity test pulmonary alveolar space width.

\begin{tabular}{ll}
\hline Variable & Sig. \\
\hline $\begin{array}{l}\text { pulmonary alveolar } \\
\text { space width }\end{array}$ & 0.252 \\
\hline
\end{tabular}

$\mathrm{K} 1$ group against $\mathrm{K} 2, \mathrm{P} 1, \mathrm{P} 2$ and $\mathrm{P} 3$, the value of $\mathrm{p}<$ 0.05 , which means there is a significant differences. Group P1 against P2 and P3 there is no significant difference with value $\mathrm{p}=0.962$ and $\mathrm{p}=0.934(\mathrm{p} \geq 0.05)$. Group P2 against P3 there is no significant difference with value $\mathrm{p}=0.972$.

Correlation between ethanol extract of mangosteen peel with doses of $0,50 \mathrm{mg} / \mathrm{Kg}, 100 \mathrm{mg} / \mathrm{Kg}$ and $200 \mathrm{mg} / \mathrm{Kg}$ and the pulmonary alveolar space width have a distribution is not normal, then using the Spearman 
correlation test $(\alpha=0.05)$ found a significant negative correlation ( $p=0.044$. $C=-415)$, meanings the greater the dose will be smaller pulmonary alveolar space width. Normality test results per group between extract ethanol of mangosteen peel with doses $0,50 \mathrm{mg} / \mathrm{Kg}$, $100 \mathrm{mg} / \mathrm{Kg}, 200 \mathrm{mg} / \mathrm{Kg}$ with the number alveolar macrophage cells and extract ethanol of mangosteen peel with doses $0,50 \mathrm{mg} / \mathrm{Kg}, 100 \mathrm{mg} / \mathrm{Kg}, 200 \mathrm{mg} / \mathrm{Kg}$ with the pulmonary alveolar space width. The ethanol extract of mangosteen peel dose of $0,100 \mathrm{mg} / \mathrm{Kg}, 200 \mathrm{mg} / \mathrm{Kg}$ had normal data distribution, the Pearson correlation test $(\alpha=0.05)$ obtained a dose of 0 , negative correlation was not significant $(\mathrm{p}=0.352 . \mathrm{C}=-466)$, dose of 100 $\mathrm{mg} / \mathrm{Kg}$, negative correlation was not significant $(\mathrm{p}=$ 0.238 . $\mathrm{C}=-570$ ), dose of $200 \mathrm{mg} / \mathrm{Kg}$, negative correlation was not significant $(\mathrm{p}=0.446 . \mathrm{C}=-389)$. The ethanol extract of mangosteen peel dose of $50 \mathrm{mg} / \mathrm{Kg}$, has a data distribution is not normal, then the Spearman correlation test $(\alpha=0.05)$, negative correlation were not significant ( $\mathrm{p}=0.173$. $\mathrm{C}=-638)$, means increasing the number of alveolar macrophage cells is not accompanied with the increasing the pulmonary alveolar space width of the entire group, and vice versa.

Table 7. LSD test pulmonary alveolar space width.

\begin{tabular}{ccc}
\hline & & $\mathrm{p}$ \\
\hline $\mathrm{K} 1$ & $\mathrm{~K} 2$ & $0.000^{\mathrm{a}}$ \\
& $\mathrm{P} 1$ & $0.000^{\mathrm{a}}$ \\
& $\mathrm{P} 2$ & $0.000^{\mathrm{a}}$ \\
& $\mathrm{P} 3$ & $0.000^{\mathrm{a}}$ \\
\hline $\mathrm{K} 2$ & $\mathrm{P} 1$ & $0.038^{\mathrm{a}}$ \\
& $\mathrm{P} 2$ & $0.042^{\mathrm{a}}$ \\
& $\mathrm{P} 3$ & $0.045^{\mathrm{a}}$ \\
$\mathrm{P} 1$ & $\mathrm{P} 2$ & $0.962^{\mathrm{b}}$ \\
& $\mathrm{P} 3$ & $0.934^{\mathrm{b}}$ \\
\hline $\mathrm{P} 2$ & $\mathrm{P} 3$ & $0.972^{\mathrm{b}}$ \\
\hline
\end{tabular}

a significant $(\alpha<0.05)$

b not significant $(\alpha \geq 0.05)$

\section{DISCUSSION}

Smoking is the main factor of the development of COPD, the lung increase in inflammatory cells such as alveolar macrophage, neutrophil, and CD8-T, lymphocyte. Inflammatory cells will release ROS through oxidation Nicotinamid Adenine Dinucleotide Phosphat (NADPH). Inflammatory response caused by cigarette will also release proinflammatory mediators that lead to the widening of lower airway and alveolar damage (Yao et al 2008).

The concentration of carbon dioxide in cigarette 200x compared in the atmosphere, it can cause inflammation in the lung. In vivo lung damage histologically with the presence of inflammatory response and oxidative stress due to exposure to cigarette smoke. In the first hour of stress, there is an inflammatory response in the form of increased epithelial permeability, neutrophil, alveolar macrophage. The extract of mangosteen peel can reduce gamma glutamyltransferase $(\gamma-\mathrm{GT})$ activity in the blood serum in research with mice exposed to cigarette smoke (Raharjo \& Santoso 2014)

\section{Alveolar macrophage cell}

Alveolar macrophage cells are cells contained in the respiratory system is in the alveoli and respiratory parenchyma. Alveolar macrophage in the form of a large cell with a diameter 15-50 $\mu \mathrm{m}$, located in interalveolar septa. Alveolar macrophages have a single cell nucleus that is located in the middle of the cell. Cytoplasm contains lysosomes organelles primary and secondary, as well as carbon particles, for example, cigarette smoke (Ovalle \& Nahirney 2008).

Alveolar macrophage /dust cell had phagocyte foreign body in the lumen of the alveoli and septum interalveolar. The cells will phagocyte particles, such as dust and bacteria, to sterilize the environment in the lung. Approximately 100 million macrophage migrate to the bronchial every day and transported through the bronchial cilia movement towards the pharynx to be removed by means of swallowed or coughed. Some alveolar macrophages will go back into the lung interstitium and migrate into the lymph vessels to get out of the lungs (Junqueira et al 2005). Humic acid can release divalent iron which is the result of smoking reduction and binds to alveolar macrophage causing bond with ferritin. Deposits of iron in the form of pulmonary emphysema materials blackish brown. Iron in alveolar macrophage is very high in smokers (van Eijl et al 2011).

Figure 1 we can see in the group K2 (cigarette smoke) are the average number of alveolar macrophage cells 76 per field of view microscope. This amount among most other groups. P1, P2, P3 groups mean fewer number of alveolar macrophage cells with the ethanol extract of mangosteen peel, the ethanol extract of mangosteen peel table 2 provides multilevel dose reduction in the number of cells than the cell size also seemed smaller than in group $\mathrm{K} 2, \mathrm{P} 1$ group mean $44.33 \pm 5.75, \mathrm{P} 2$ group 40.33 \pm 6.89 and $\mathrm{P} 332.33 \pm 3.50$. Provision of prior exposure to cigarette smoke ethanol extract of mangosteen peel to give effect to prevent an increase in the number of alveolar macrophage cells. Mangosteen peel beneficial for health because it contain anthocyanin, tannin, compound phenol/polyphenol, epikathekin and xanthone, which act as antioxidants, antidiabetic, anticancer, anti inflammatory, hepatoprotective, anti- 
bacteria (Wiwin et al 2010). Xanthone as antioxi-dants can break down (scavengers) free radicals, thereby reducing the formation of free radicals through the system Celestion namely iron ions move so that the number of alveolar macrophage cells is reduced (Jiang et al 2004)

Based on the data in table 2 decreased the number of alveolar macrophage cells in the group P1, P2 and P3 that received the ethanol extract of mangosteen peel dose $50 \mathrm{mg} / \mathrm{kg}, 100 \mathrm{mg} / \mathrm{kg}$, and $200 \mathrm{mg} / \mathrm{kg}$. In table 3 it can be seen that the data normality test value $p>\alpha$ so that all the data on each of these groups normally distributed. Homogeneity test with $\mathrm{p}=0.004(\mathrm{p}<\alpha)$, which means that the data are not homogeneous, so as to test Post Hoc tests conducted by Tamhane's T2 test. After the test Anova (Robust tests - Brown-Forsythe). The test was obtained $p=0.000(p<\alpha)$ so the data has variation with significant differences in all groups both control and treatment. Statistical test to test Tamhane's $\mathrm{T} 2$ (table 3) group $\mathrm{K} 1$ (just got the solution $\mathrm{Na}-\mathrm{CMC}$ $0.5 \%$ ) showed no significant difference to the group P1, $\mathrm{P} 2, \mathrm{p}>0.05$, but differ significantly on the group P3. It is indicated that the ethanol extract of mangosteen peel at a dose of $200 \mathrm{mg} / \mathrm{kgBB}$ can reduce significantly the number of alveolar macrophage cells of the group control, other factors that influence the number of alveolar macro-phage cells is possible, one of which is the number of samples that only 6 per group.

K2 (cigarette smoke) showed significant differences for all groups, it means giving a smoke greatly increase the number of alveolar macrophage cells, but with a dose $50 \mathrm{mg} / \mathrm{kg}$ of the ethanol extract of mangosteen peel has demonstrated a significant reduction in cell. P1 groups showed no significant difference to the group P2, but significant to P3, P2 groups showed no significant difference to the group P3, this means the required dosage sufficient $50 \mathrm{mg} / \mathrm{kg}$ to reduce the number of alveolar macrophage cells in the lung, but if require higher doses it must $4 \mathrm{x}$ intial dose of $200 \mathrm{mg} / \mathrm{kg}$ in order to obtain a significant reduction in the number of alveolar macrophage cells. Correlation between the dose and groups $\mathrm{K} 2, \mathrm{P} 1, \mathrm{P} 2$ and $\mathrm{P} 3$ the number of alveolar macrophage cells indicates there is a negative correlation, meaning there is a relationship of mutual influence with increasing dose will decrease the number of alveolar macrophage cells in this research.

\section{Pulmonary alveolar space width}

Damage that occurs as a result of smoking on airway another form of breakdown of extracellular matrix in disease emphysema. The occurrence of pulmonary emphysema known as antiproteases- protease equilibrium theory. Lung connective tissue provides protection (leukocyte protease) that is endogenous protease inhibitors. Mechanisms regulating the development of emphysema is $\alpha 1 \mathrm{PI}$ ( $\alpha 1$-proteinase inhibitor) polymorphonuclear neutrophil (PMN) in the lower respiratory tract. In research with mice exposed to smoke a decline in serum elastase inhibitor capacity (EIC) also on human lung fluid. EIC decline is not the result of a decrease in the levels of $\alpha$ lPI but of the formation of the protein inactive the rest of the oxidation of methionine. Although only one methionine residue at the active site but very essential $\alpha$ lPI binds to the protein elastase (Church \& Pryor 1985). Microscopic emphysema, alveoli looks great, separated by a thin septum obtained with only focal fibrosis sentriasinus. Alveolar attachment to the outer wall of the airway disappear. Khon pores so large that simply septum protruding into the alveolar cavity with a maceshape tip (Kumar et al 2005).

The results of this study the data obtained in the figure 2 , group $\mathrm{K} 2$ increase the average $4731.35 \mu \mathrm{m} 2$ width of the alveolar spaces. The value is the average width of the most extensive alveolar space when compare with the control group K1 and the treatment group P1, P2 and $\mathrm{P} 3$. In the treatment group were given protection the ethanol extract of mangosteen peel group P1 (50 $\mathrm{mg} / \mathrm{kg})$, group P2 (100 mg/kg) and group P3 (200 $\mathrm{mg} / \mathrm{kg}$ ) there is a wide mean alveolar spaces in a row $3846.64 \mu \mathrm{m} 2 \pm 634.55 ; 3846.81 \mu \mathrm{m} 2 \pm 638.14$ and $3880.332 \mu \mathrm{m} 2 \pm 1055.82$ (table 5).

In table 6 it can be seen that the value of data normality test $p>\alpha$ so that all the data on each of these groups normally distributed, except for groups P1. Homogeneity test obtained value $p=0.252(p>\alpha)$ which means the data is homogeneous. After fulfilling both of these requirements can be performed Anova one-way analysis test. The test values obtained $p=0.000(p<\alpha)$ so the data has variation with significant differences in overall group control and treatment. Each group performed LSD test (Least Significant Different) to compare each group with each other. LSD test results obtained K1 group have significant differences to the group $\mathrm{K} 2, \mathrm{P} 1$, $\mathrm{P} 2, \mathrm{P} 3$. K2 group have significant differences to the other group, but P1, P2, P3 groups does not have significant differences, it can be concluded that only require a low dose is $50 \mathrm{mg} / \mathrm{kg}$ to prevent the dilation of pulmonary alveolar space, when the dose was increased, the effect is in getting it made no difference/insignificant or in need of a larger sample to detect a significant difference.

Correlation between the dose with pulmonary alveolar space width K2, P1, P2 and P3 group obtained a negative correlation, meaning there is a relationship of mutual influence between the dose and the width of the 
alveolar spaces in this study, increasing the dose will decrease the width of pulmonary alveolar space. Correlation between the dose of the ethanol extract of mangosteen peel with a mean number of alveolar macrophage cells and the ethanol extract of mangosteen peel dose with a mean width of the alveolar spaces, there was no significant correlation with increasing doses of the ethanol extract of mangosteen peel will affect a decrease in the number of alveolar macrophage cells but does not appear to affect the width of pulmonary alveolar space. Correlation of the average number of alveolar macrophage cells and the average width of the alveolar spaces, does not appear, it means an increase in the mean number of alveolar macrophage cells is not accompanied by an increase in the mean width of the alveolar spaces, the whole group, and vice versa.

These studies have the limitation that the necessary suggestions fo further improvement. Further study using a larger sample, allowing a correlation between the average number of alveolar macrophage cells with an average width of alveolar space. Further research needs to be done on all parts of the respiratory tract such as the trachea, bronchus, goblet cells, cell neutrophils, mast cells in order to provide the full picture damage caused by cigarette. Histochemical examination can also be performed an alveolar lung, namely IL- 8 chemokines, genetic ablation, protease activity, caused by cigarette. Other research on the ethanol extract of mangosteen peel as curative therapy.

\section{CONCLUSION}

Based on the results of current research, there is the effect of the ethanol extract of mangosteen peel in NaCMC $0.5 \% 50 \mathrm{mg} / \mathrm{kg}, 100 \mathrm{mg} / \mathrm{kg}, 200 \mathrm{mg} / \mathrm{kg}$ for 14 days for histological number and width of the alveolar macrophage cell lung alveolar space white male rats (Rattus norvegicus) were exposed to cigarette smoke. There is a correlation the ethanol extract of mangosteen peel in Na-CMC $0.5 \% 50 \mathrm{mg} / \mathrm{kg}, 100 \mathrm{mg} / \mathrm{kg}, 200 \mathrm{mg} / \mathrm{kg}$ for 14 days for histological number and width of the alveolar macrophage cell lung alveolar space white male rats (Rattus norvegicus) were exposed to cigarette smoke. There is no correlation between the number and width of alveolar macrophage cell lung alveolar space white male rats (Rattus norvegicus), this means an increase in the average number of alveolar macrophage was not accompanied by an increase in the average width of the alveolar spaces, the entire group and vice versa.

\section{REFERENCES}

Church DF and Pryor WA (1985). Free-radical chemistry of cigarette smoke and its toxicological implications. Environ Health Perspect 64, 111-126

van Eijl S, Mortaz E, Ferreira AF, Kuper F, Nijkamp FP, Folkerts G, Bloksma N (2011). Humic acid enhances cigarette smoke-induced lung emphysema in mice and IL-8 release of human monocytes. Pulm Pharmacol Ther 24, 682-689

Jain A, Agrawal BK, Varma M, Jadhav AA (2009). Antioxidant status and smoking habits: relationship with diet. Singapore Med J 50, 624-627

Jiang DJ, Dai Z, Li YJ (2004). Pharmacological effects of xanthones as cardiovascular protective agents. Cardiovasc Drug Rev 22, 91-102

Junqueira L and Carneiro J (2005). Basic Histology: Text \& Atlas (Junqueira's Basic Histology) 11th Ed, New York, McGraw-Hill Medical

Kumar V, Abbas AK, Fausto N (2005). Robbins \& Cofran Dasar Patologi Penyakit Edisi 7, Jakarta, EGC Emergency Arcan Buku Kedokteran, p 730-793

Lei J, Huo X, Duan W, Xu Q, Li R, Ma J, Li X, Han L, Li W, Sun H, Wu E, Ma Q (2014). $\alpha$-Mangostin inhibits hypoxia-driven ROS-induced PSC activation and pancreatic cancer cell invasion. Cancer Lett 347, $129-138$

Moore KL (2002). Anatomi Klinis Dasar (Essential Clinical Anatomy). Interpreter: Agur AMR and Laksman H. Jakarta, Hipokrates, p 45-54

Ovalle WK and Nahirney PC (2008). Netter's Essential Histology, 1st Ed, Philadelphia, Elsevier Inc, p 343351

Petiwala SM, Li G, Ramaiya A, Kumar A, Gill RK, Saksena S, Johnson JJ (2014). Pharmacokinetic characterization of mangosteen (Garcinia mangostana) fruit extract standardized to $\alpha$-mangostin in C57BL/6 mice. Nutr Res 34, 336-345

Raharjo LH and Santoso HTAL (2014). Ekstrak kulit buah manggis menurunkan aktifitas gamma glutamyltransferase $(\gamma-\mathrm{GT})$ serum pada paparan asap rokok. Jurnal Ilmiah Kedokteran 3, 29-39

Schmieder A, Schwaiger S, Csordas A, Backovic A, Messner B, Wick G, Stuppner H, Bernhard D (2007). Isogentisin--a novel compound for the prevention of smoking-caused endothelial injury. Atherosclerosis 194, 317-325

Sosa V, Moliné T, Somoza R, Paciucci R, Kondoh H, LLeonart ME (2013). Oxidative stress and cancer: an overview. Ageing Res Rev 12, 376-390

Wilkins RL and Gold PM (2007). Chronic obstructive pulmonary disease. In: Wilkins RL, Dexter JR, Gold PM (eds). Respiratory Disease: A Case Study Approach to Patient Care, Third Ed, Philadelphila, FA Davis Company, p 68-98 
Wiwin S, Endang DW, Lia K (2010). Uji akivitas antioksidan dan penentuan kandungan antosianin total kulit buah manggis (Garcinia mangostana L). Majalah Obat Tradisional 15, 64-70

Yao H, Edirisinghe I, Yang SR, Rajendrasozhan S, Kode A, Caito S, Adenuga D, Rahman I (2008).
Genetic ablation of NADPH oxidase enhances susceptibility to cigarette smoke-induced lung inflammation and emphysema in mice. Am J Pathol $172,1222-1237$ 